\title{
ACCELERATED STABILITY STUDIES OF FLURBIPROFEN FILM COATED TABLETS OF FIVE DIFFERENT NATIONAL BRANDS IN PAKISTAN
}

\author{
Usman Faisal $^{1^{*}}$, Javed Ibrahim ${ }^{1}$, Saeed-ur-Rasheed ${ }^{2}$, Nazar M. Ranjha ${ }^{1}$, Liaqat Hussain ${ }^{3}$, Asif Massud ${ }^{3}$ \\ ${ }^{1}$ Faculty of Pharmacy, Bahauddin Zakariya University, Multan, Pakistan \\ ${ }^{2}$ Faculty of Pharmacy, University of Sargodha, Sargodha, Pakistan \\ ${ }^{3}$ Department of Pharmacy, Government College University, Faisalabad, Pakistan \\ *Corresponding author: Tel.: +923335569874, Email address: usmanfaisal63@yahoo.com
}

\begin{abstract}
Flurbiprofen is a potent non-steroidal anti-inflammatory drug, prescribed commonly for musculoskeletal and joint disorders like arthritis. It is well established that drug degradation during storage and transportation is of particular issue in tropical countries like Pakistan, having areas with temperature variations from $0^{\circ} \mathrm{C}$ (Muree, Islamabad, Sawat and Azad Jammu Kashmir) to $50^{\circ} \mathrm{C}$ (Sibi, Jackababad, Nawabshah, Larkana, Multan and Bahawalpur) and some areas with high relative humidity (Karachi). Present study was designed to evaluate five different national brands of flurbiprofen $100 \mathrm{mg}$ film coated tablets by accelerated stability studies and examined for the parameters of hardness, disintegration, dissolution and assay for drug concentration in formulation after one, three and six months duration at controlled tropical conditions of temperature and relative humidity. Dosage forms of all selected national brands were found stable even after expiry date.

Keywords: Flurbiprofen, Accelerated stability study, Dissolution, Disintegration, Assay
\end{abstract}

\section{INTRODUCTION}

Stability of pharmaceutical products is important for patient's safety ${ }^{1}$ and stability calculations of expiration date of the product ${ }^{2}$. Stability of pharmaceutical product means the physical and chemical integrity of dosage form and its ability to guard against microbial contamination ${ }^{3}$. Pharmaceutical products adopt various pathways of chemical degradation including hydrolysis, oxidation, deamination and cyclization ${ }^{4}$. Accelerated stability studies are performed in order to predict the long term stability of pharmaceutical products ${ }^{5}$. They also help to identify the major degradation products; degradation pathways and stability indicating potential of analytical procedure used $^{6}$.These studies are performed by exposing the representative sample of pharmaceutical product to stress conditions of temperature, humidity, light and radiations. Most companies conduct some types of accelerated degradation studies but companies' practices vary widely in term of when and how these studies are to performed ${ }^{8}$. Flurbiprofen is a chiral, 2-arylpropionic acid derived nonsteroidal anti inflammatory drug having potent cyclooxegenase non selective inhibition activity ${ }^{8}$, shorter biological half-life and stereoselective pharmacokinetics ${ }^{9}$. It is used for the treatment of musculoskeletal and joint disorders like arthritis and acute gout. Film coated flurbiprofen tablets are elegant in appearance and improved gastric tolerability ${ }^{11}$.

The aim of this study was to conduct accelerated stability studies of $100 \mathrm{mg}$ film coated flurbiprofen tablets from different national brands in Pakistan in order to evaluate the parameters of dissolution, disintegration, hardness and drug potency (WHO guidelines for stability testing, 2006) $)^{11}$ at different time intervals of 1,3 and 6 months as function of temperature and relative humidity at tropical conditions according to ICH guidelines, 2003.

\section{MATERIALS AND METHODS}

Flurbiprofen $100 \mathrm{mg}$ film coated tablets, which were 5 months near to their expiration date, of five different national brands i.e. Flurbin $\AA$, Rubinol $\AA$, Flurle $\AA$, Frugesic $\AA$, Eyeflox $®$ were collected randomly from Mass pharma (Pvt) Ltd. Lahore, Obsons Pharmaceuticals (Pvt) Ltd. Lahore, Leads Pharma (Pvt) Ltd. Islamabad, Mediceena Pharma (Pvt) Ltd. Lahore, P.D.H Pharmaceuticals (Pvt) Ltd. Lahore respectively. Hardness tests were performed on MH-1 Galvano Scientific while for disintegration and dissolution tests, basket-rack assembly USP 30 (Galvano Scientific) and six stations USP 30 type II paddle apparatus (Galvano Scientific) were used respectively. Assay for concentration of flurbiprofen was performed on Optizen $2010 \mathrm{UV}$ and was also determined by titrometric analysis. All other chemicals used were of analytical grade and were used without any chemical modification.

\section{Accelerated Stability Studies}

Flurbiprofen $100 \mathrm{mg}$ film coated tablets in form of packs in triplets were placed in stability chamber with controlled temperature and humidity of class IV climatic conditions as recommended by ICH guidelines 2007. Temperature was maintained at $40 \pm 2^{\circ} \mathrm{C}$ and relative humidity was controlled by KCI solution at RH $75 \pm 5 \%$.

\section{Tablet hardness}

Hardness of tablets was determined by placing them in plungers of Hardness Tester, measuring the average force in Kilogram by triplicate of tests.

\section{Disintegration studies}

Disintegration studies were performed according to USP 30 specifications. Six tablets were placed in basket rack assembly of apparatus. Basket was moved with frequency 
Faisal et al

Journal of Drug Delivery \& Therapeutics; 2013, 3(2), 9-11

of 29 to 32 cycles per minute in distilled water, maintained at $37 \pm 2^{\circ} \mathrm{C}$.

\section{Dissolution studies}

In vitro drug release studies were performed by dissolution test USP 30 for 6 hours, using phosphate buffer at $\mathrm{pH}$ of $7.20 \pm 0.05$ maintained at $37 \pm 2^{\circ} \mathrm{C}$ as dissolution medium for film coated tablet and measuring the absorbance at $247 \mathrm{~nm}$ at UV visible spectrophotometer. Sample of $5 \mathrm{ml}$ was first taken after 45 minutes and then after every 30 minutes and replaced by fresh dissolution medium to maintain the volume. Concentration of drug in sample was measured, after filtration and dilution, by calibration curves and percentage drug release was calculated.

\section{Assay}

Assay was performed by two ways;

Titrimetric Analysis

20 tablets were crushed and powdered. Powder weighing equivalent to $200 \mathrm{mg}$ flurbiprofen was dissolved in $50 \mathrm{ml}$ $(96 \%)$ methanol. This solution was titrated against $0.1 \mathrm{M}$
$\mathrm{NaOH}$, determining end point potentiometrically. $1 \mathrm{ml}$ of $0.1 \mathrm{M}$ of $\mathrm{NaOH}$ is equivalent to $24.43 \mathrm{mg}$ of $\mathrm{C}_{15} \mathrm{H}_{13} \mathrm{FO}_{2}{ }^{12}$.

\section{Spectrophotometric analysis}

Spectrophotometric analysis was performed on UV visible spectrophotometer. Standard was prepared of $0.01 \mathrm{mg} / \mathrm{ml}$ by dissolving $100 \mathrm{mg}$ of flurbiprofen in $100 \mathrm{ml}$ of $0.01 \mathrm{~N}$ $\mathrm{NaOH}$ and then diluting it. Sample solution was prepared by crushing and powdering 20 flurbiprofen tablets and dissolving powder weighing equivalent to $100 \mathrm{mg}$ flurbiprofen in $100 \mathrm{ml}$ of $0.01 \mathrm{~N} \mathrm{NaOH}$ and diluting upto $0.01 \mathrm{mg} / \mathrm{ml}$. Absorbance was measured at $247 \mathrm{~nm}$ and percentage of flurbiprofen was determined as ${ }^{13}$

Percentage of flurbiprofen $=($ A sample $\times 100) /$ A standard

Where A is Absorbance. Acceptable limits were 90-110\%.

Assay was performed as triplicate of both methods and drug concentration in tablet was measured as average.

\section{RESULTS}

Tablet hardness

Table 1: Hardness of different brands of flurbiprofen $100 \mathrm{mg}$ film coated tablets

\begin{tabular}{|c|c|c|c|}
\hline \multirow{2}{*}{ Brands } & \multicolumn{3}{|c|}{$\begin{array}{c}\text { Hardness (average) } \\
\left(\mathrm{kg} / \mathrm{cm}^{2} / \text { tablet }\right)\end{array}$} \\
\cline { 2 - 4 } & One month & Three month & Six month \\
\hline Flurbin & 7.6 & 7.5 & 6.1 \\
\hline Rubinol & 7.3 & 7.2 & 6.5 \\
\hline Flurle & 8.1 & 7.7 & 6.8 \\
\hline Frugesic & 7.8 & 7.5 & 7.2 \\
\hline Eyeflox & 8.5 & 8.1 & \\
\hline
\end{tabular}

\section{Disintegration studies}

Table 2: Results of disintegration studies of different brands of flurbiprofen $100 \mathrm{mg}$ film coated tablets

\begin{tabular}{|c|c|c|c|}
\hline \multirow{2}{*}{ Brands } & \multicolumn{3}{|c|}{$\begin{array}{c}\text { Disintegration time (average) } \\
\text { (min) }\end{array}$} \\
\cline { 2 - 4 } & One month & Three month & Six month \\
\hline Flurbin & 8.10 & 7.95 & 7.10 \\
\hline Rubinol & 8.21 & 8.13 & 7.25 \\
\hline Flurle & 8.61 & 8.43 & 8.15 \\
\hline Frugesic & 8.95 & 8.65 & 7.88 \\
\hline Eyeflox & 8.25 & 8.05 & \\
\hline
\end{tabular}

\section{Dissolution studies}

Table 3: Results of dissolution studies of different brands of flurbiprofen 100mg film coated tablets

\begin{tabular}{|c|c|c|c|}
\hline \multirow{2}{*}{ Brands } & \multicolumn{3}{|c|}{$\begin{array}{c}\text { Dissolution (average) } \\
\text { (\%age) }\end{array}$} \\
\cline { 2 - 4 } & One month & Three month & Six month \\
\hline Flurbin & 91.32 & 86.45 & 78.53 \\
\hline Rubinol & 95.82 & 89.33 & 70.52 \\
\hline Flurle & 99.24 & 92.52 & 76.83 \\
\hline Frugesic & 90.40 & 83.53 & 79.90 \\
\hline Eyeflox & 92.05 & 85.38 & \\
\hline
\end{tabular}


Table 4: Results of assays of different brands of flurbiprofen $100 \mathrm{mg}$ film coated tablets

\begin{tabular}{|c|c|c|c|}
\hline \multirow{2}{*}{ Brands } & \multicolumn{3}{|c|}{$\begin{array}{c}\text { Assay (average) } \\
\text { (\%age) }\end{array}$} \\
\cline { 2 - 4 } & One month & Three month & Six month \\
\hline Flurbin & 99.76 & 97.65 & 91.5 \\
\hline Rubinol & 102.26 & 101.61 & 96.40 \\
\hline Flurle & 98.62 & 98.33 & 90.81 \\
\hline Frugesic & 95.39 & 94.99 & 95.33 \\
\hline Eyeflox & 102.10 & 101.85 & \\
\hline
\end{tabular}

\section{DISCUSSION}

Flurbiprofen is a potent NSAID been in clinical use for many years. Formulation tests recommended in pharmacopoeia monographs are useful in determining in vivo efficacy. Hardness of tablets, after keeping in stability chamber for 6 months at controlled temperature and humidity was not significantly affected up to 3 months of studies as tablet gains moisture and its hardness increases then subsequently loose $i^{14}$ whereas hardness of all brands decreased after six months significantly. Disintegration and dissolution decreased in same manner during 6 months studies, under increased humidity. However difference of disintegration pattern from that of hardness can be justified due to excipients function ${ }^{15}$. Assay of five different brands was conducted by both spectrophotometer and titrimetric analysis, and results were calculated as average, and

\section{REFERENCE}

1. Waterman KC, Adami RC, Accelerated aging: Prediction of chemical stability of pharmaceuticals, International Journal of Pharmaceutics, 2005, 293(1), 101-125.

2. Lee $\mathrm{H}, \mathrm{Wu} \mathrm{P}$, Lee $\mathrm{Y}$, stab: An R package for drug stability data analysis, Computer Methods and Programs in Biomedicine, 2010, 100(2), 140-148.

3. Shakeel F, Baboota S, Ahuja A, Ali J, Shafiq S, Accelerated stability testing of celecoxib nanoemulsion containing Cremophor-EL, African Journal of Pharmacy and Pharmacology, 2008, 2(8), 179-183.

4. Byrn SR, Xu W, Newman AW, Chemical reactivity in solid-state pharmaceuticals: formulation implications, Advanced Drug Delivery Reviews, 2001, 48(1), 115-136.

5. Fitzpatrick S, McCabe JF, Petts CR, Booth SW, Effect of moisture on polyvinylpyrrolidone in accelerated stability testing, International Journal of Pharmaceutics, 2002, 246(1), 143-151.

6. International Conference on Harmonization, 2003. ICH Q1A(R2): Stability Testing of New Drug Substances and Products. Page 2.

7. Alsante KM, Martin L, Baertschi SW, A stress testing benchmarking study, Pharmaceutical Technology, 2003, 27(2), 60-73.

8. Fu H, Chen H, Wang C, Xu H, Liu F, Guo M, Wang Q, Shi X, Flurbiprofen, Cyclooxygenase Inhibitor, Protects Mice from Hepatic Ischemia/Reperfusion Injury by Inhibiting GSK-3 results were in the range of $90-110 \%$ USP 30 and there was no marked effect on assay of brands taken for studies.

From above discussed data, flurbiprofen film coated tablets of all national brands have been found stable even after expiry date. Therefore, it has been concluded that stability study of flurbiprofen found equally accurate, reproducible, robust, and could be applied directly and easily to the pharmaceutical preparations of flurbiprofen. However excipients function was not taken into account which can impart deviation from above results.

\section{ACKNOWLEDGEMENT}

Authors are thankful to Shifa Pharmacy Faisalabad, Punjab, Pakistan for provision of required brands of flurbiprofen tablets for study.

Signaling and Mitochondrial Permeability Transition, Molecular Medicine, 2012, 18, 1128-1135.

9. Davies NM, Toxicity of nonsteroidal anti-inflammatory drugs in the large intestine, Diseases of the Colon \& Rectum, 1995, 38(12), 1311-1321.

10. Ahmad M, Pervaiz F, Comparative bioavailability and pharmacokinetics of investigational enteric-and film-coated formulations of flurbiprofen 100-mg tablets: a single-dose, randomized, open-label, two-period, two-way crossover study in healthy Pakistani male volunteers, Clinical Therapeutics, 2010, 32(3), 607.

11. World Health Organization, 2006. Stability testing of active substances and Pharmaceutical products, April.

12. European Pharmacopoeia, 2005. Flurbiprofen, Monograph 1519. Council of Europe, Strasbourg, France.

13. United States Pharmacopeia (USP), 2007. United States Pharmacopoeia Convention, 30

14. Late SG, Yu YY, Banga AK, Effects of disintegration-promoting agent, lubricants and moisture treatment on optimized fast disintegrating tablets, International Journal of Pharmaceutics, 2009, 365(1), 4-11.

15. Bhagawati S, Hiremath S, Sreenivas S, Comparative evaluation of disintegrants by formulating cefixime dispersible tablets, Indain Journal of Pharmaceutical Education, 2005, 39(4), 194. 